\title{
Faith and Scepticism in Private International Law: Trust, Governance, Politics, and Foreign Judgments
}

\author{
Christopher Whytock*
}

\begin{abstract}
In both the European Union (EU) and the United States (US), the law governing the enforcement of foreign judgments is evolving, but in different directions. EU law, especially after the elimination of exequatur by the 2012 'Recast' of the Brussels I Regulation, increasingly facilitates enforcement in member states of judgments of other member states' courts, reflecting growing faith in a multilateral private international law approach to foreign judgments. In US law, on the other hand, increasingly widespread adoption of state legislation based on the 2005 Uniform ForeignCountry Money Judgments Recognition Act (2005 Act), which adds new case-specific grounds for refusing enforcement, suggests growing scepticism. In this essay, I explore possible reasons for these diverging trends. I begin with the most obvious explanation: the Brussels framework governs the effect of internal EU member state judgments within the $\mathrm{EU}$, whereas the 2005 Act governs the effect of external foreign country judgments within the US. One would expect more mutual trust - and thus more faith in foreign judgment enforcement - internally than externally. But I argue that this mutual trust explanation is only partially satisfactory. I therefore sketch out two other possible explanations. One is that the different trends in EU and US law are a result of an emphasis on 'governance values' in EU law and an emphasis on 'rights values' in US law. Another explanation - and perhaps the most fundamental one - is that these trends are ultimately traceable to politics.
\end{abstract}

Keywords: private international law, conflict of laws, foreign judgments, European Union, United States

\section{Introduction}

'It is time to stop pretending that Europeans and Americans share a common view of the world .... ${ }^{1}$ So begins Robert Kagan's 2003 book, Of Paradise and Power: America and Europe in the New World Order. Writing about differences between European and American strategic culture, Kagan argued that Europe favors multilateral solutions to global problems, while the American impulse is unilateral. ${ }^{2}$ American exceptionalism 'may be welcomed, ridiculed, or lamented. But it should not be doubted.'

Recent developments suggest that similar differences may exist in European and American approaches to one of the main branches of private international law: the enforcement of foreign country judgments. In both the European Union (EU) and the United States (US), this area of law is evolving - but in different directions. Within the EU, the law increasingly facilitates the enforcement in member states of the judgments of other member states, reflecting a growing faith in a multilateral private international law approach to foreign judgments. Most notably, the 2012 'Recast' of the Brussels I Regulation (Brussels I Recast) promises to streamline enforcement by eliminating the declaration of enforceability (exequatur) as a requirement for the enforcement of EU member state judgments in civil and commercial matters. ${ }^{4}$ In US law, on the other hand, there is evidence of growing scepticism and insistence on more searching unilateral US review of foreign country judgments. In particular, US states are increasingly adopting legislation based on the 2005 Uniform Foreign-Country Money Judgments Recognition Act (2005 Act), which contains two new grounds for refusing enforcement: one that allows non-enforcement if 'the judgment was rendered in circumstances that raise substantial doubt about the integrity of the rendering court with respect to the judgment' and the other if 'the specific proceeding in the foreign court leading to the judgment was not compatible with the requirements of due process of law. ${ }^{5}$

In this essay I offer some comparative reflections on these trends. I first develop the claim that EU law

* Christopher Whytock is Professor of Law and Political Science at the University of California, Irvine School of Law. For helpful comments on an earlier draft of this essay, I thank Bill Dodge, Deborah Hensler, Stefaan Voet, participants at the Bay Area Procedural Forum at University of California, Hastings College of Law, and two anonymous reviewers.

1. R. Kagan, Of Paradise and Power: America and Europe in the New World Order (2003), at 3. 
exhibits increasing faith, and US law increasing scepticism, regarding foreign judgments. I then explore possible reasons for this divergence. I begin with the most obvious explanation: the territorial scope of the law. The Brussels framework applies to internal judgments - that is, it governs the effect of EU member state judgments in other EU member states in a way that is somewhat comparable to the US law of full faith and credit that governs the effect of US state judgments in other US states. ${ }^{6}$ In contrast, the 2005 Act governs external judgments - that is, it governs the effect of foreign country judgments in US states in a way that is comparable to the law of individual EU member states governing the judgments of non-EU members. ${ }^{7}$ One would reasonably expect more mutual trust - and thus more faith in foreign judgment enforcement - internally than externally. But I argue that this mutual trust explanation is only partially satisfactory. I therefore sketch out two other possible explanations. One is that the different trends in EU and US law are a result of an emphasis on 'governance values' in EU private international law and an emphasis on 'rights values' in US law. Another explanation - and perhaps the most fundamental one - is that these trends are ultimately traceable to politics.

\section{Faith/Scepticism}

114 Private international law - or 'conflict of laws,' as it is known in the US - is a particular approach to global governance. ${ }^{8}$ Private international law tolerates decentralised governance authority and diverse laws and legal institutions. It handles this decentralisation and diversity with principles intended to guide the allocation of governance authority among nations. ${ }^{9}$ Generically, the principles of private international law are statements of circumstances in which one nation may, must or must not defer to another nation by respecting its legal proceedings, applying its law, or recognising its court judgments. They are, in other words, principles of conditional deference.

International organisation and harmonisation are different approaches to global governance. International

6. See Article 2 of Brussels I Recast (defining 'judgment' for purposes of the regulation as 'any judgment given by a court or tribunal of a Member State').

7. See Section 2(2) of 2005 Act (defining 'foreign-country judgment' for purposes of the act as 'a judgment of a court of a foreign country'). Note that the Lugano Convention on Jurisdiction and the Enforcement of Judgments in Civil and Commercial Matters applies governs in lieu of national law in matters between EU member states and Iceland, Norway and Switzerland. Michael Bogdan, Concise Introduction to EU Private International Law (2nd edn.) (2012), at 32.

8. See H. Muir-Watt, 'Private International Law as Global Governance: Beyond the Schism, from Closet to Planet' (October 2011) (manuscript available at <http://works.bepress.com/horatia_muir-watt/1>); C.A. Whytock, 'Domestic Courts and Global Governance', 84 Tulane Law Review 67 (2009).

9. Whytock (2009), above n. 8, at 25-83. In addition, private international law helps allocate authority between private and public actors. Id. at 89-91. organisation seeks internationally agreed-upon rules applied and enforced by international institutions. Harmonisation seeks uniform national rules but depends on decentralised national institutions to adopt and apply them. Whereas private international law takes decentralisation and diversity as given, international organisation strives to eliminate the former and harmonisation strives to eliminate the latter. Private international law may be a less ambitious form of global governance in the sense that it puts up with both decentralisation and diversity, but it is also more ambitious insofar as it relies on nations to trust each other's ability to appropriately govern transnational problems.

One branch of private international law consists of procedures and principles used to determine whether to give effect, through recognition or enforcement, to a judgment of one country's court (F-1) in another country $(\mathrm{F}-2)$. The necessary procedural steps range from burdensome (e.g. the filing of a separate lawsuit in $\mathrm{F}-2$ seeking enforcement of the F-1 judgment) to relatively easy (e.g. the presentation of a certified copy of the F-1 judgment to the F-2 court). The principles of enforcement also vary. When faced with a foreign judgment, the F-2 court may take a unilateral approach whereby it independently reviews issues of law and fact to arrive at its own conclusion on the merits of the case already decided by the F-1 court - an approach known as révision au fond. Alternatively, the F-2 court may take a more multilateral approach whereby it recognises or enforces the F-2 judgment without révision au fond, but subject to specified exceptions or 'grounds for refusal.' If facilitation of enforcement is a measure of faith and grounds for refusal are a measure of scepticism toward a multilateral private international law approach to foreign judgments, then it would seem that the EU approach is increasingly characterised by faith and the US approach by scepticism.

\subsection{EU Law and the Abolition of Exequatur} EU law has made it progressively easier to enforce EU member state judgments in other EU member states. The 1968 Brussels Convention on Jurisdiction and the Enforcement of Judgments in Civil and Commercial Matters (Brussels Convention) provided that '[a] judgment given in a Contracting State and enforceable in that State shall be enforced in another Contracting State when, on the application of any interested party, the order for its enforcement [i.e. exequatur] has been issued there.' ${ }^{10}$ An application for enforcement could be refused only on the grounds specified for non-recognition, and substantive review of the judgment was prohibited. ${ }^{11}$ At the initial application stage, a judgment debtor was not entitled to make any submissions in opposition to the application, but a judgment debtor was entitled to appeal from an enforcement order and a judgment creditor was entitled to appeal from a decision

10. Article 31 of Brussels Convention on jurisdiction and the enforcement of judgments in civil and commercial matters, 1968, OJ 1972, L 299/32 (hereinafter Brussels Convention).

11. Article 34 of Brussels Convention. 
to refuse enforcement. ${ }^{12}$ If granted, the order of enforcement authorised protective measures, but other enforcement measures were subject to the appeals provisions. ${ }^{13}$

The 2001 Brussels Regulation on Jurisdiction and the Recognition and Enforcement of Judgments in Civil and Commercial Matters (Brussels I Regulation) retained but streamlined the exequatur process. ${ }^{14}$ Unlike the Brussels Convention, the Brussels I Regulation requires the enforcing court to declare the judgment enforceable upon the completion of the formalities of producing an authentic copy of the judgment and a certificate from the state of the rendering court that the judgment is enforceable there, without any review of possible grounds for non-enforcement. ${ }^{15}$ At this stage - before any review of grounds for non-enforcement - protective measures can be taken. ${ }^{16}$ But judgment debtors can raise issues of non-enforceability on appeal as they could under the Brussels Convention, and enforcement measures other than protective measures still may not be sought until any such appeal has been determined. ${ }^{17}$

An even more significant move toward streamlining the enforcement of foreign judgments came in 2012 with the adoption of the Brussels I Recast. The Brussels I Recast did not significantly change the available grounds for refusal, but these grounds are worth noting for purposes of comparison with US law: ${ }^{18}$

On the application of any interested party, the recognition of a judgment shall be refused:

(a) if such recognition is manifestly contrary to public policy (ordre public) in the Member State addressed;

(b) where the judgment was given in default of appearance, if the defendant was not served with the document which instituted the proceedings or with an equivalent document in sufficient time and in such a way as to enable him to arrange for his defence, unless the defendant failed to commence proceedings to challenge the judgment when it was possible for him to do so;

(c) if the judgment is irreconcilable with a judgment given between the same parties in the Member State addressed;

(d) if the judgment is irreconcilable with an earlier judgment given in another Member State or in a third State involving the same cause of action and between the same parties, provided that the earlier

12. Articles 34,36 and 40 of Brussels Convention.

13. Article 39 of Brussels Convention.

14. Article 38 of Regulation No. 44/2001 on jurisdiction and the recognition and enforcement of judgments in civil and commercial matters, $\mathrm{OJ}$ 2001, L 12/1 (hereinafter Brussels I Regulation).

15. Article 41 of Brussels I Regulation.

16. See Article 47(2) of Brussels I Regulation ('The declaration of enforceability shall carry with it the power to proceed to any protective measures').

17. Articles 43 and 47 of Brussels I Regulation.

18. Article 45(1) of Brussels I Recast. Under Article 46, enforcement shall be refused if one of the Article 45 grounds for refusing recognition is found to exist. These grounds basically mirror those of the Brussels I Regulation. See Articles 34-38 of Brussels I Regulation. judgment fulfils the conditions necessary for its recognition in the Member State addressed; or

(e) if the judgment conflicts with: (i) [the special jurisdictional provisions of] Sections 3, 4 or 5 of Chapter II where the policyholder, the insured, a beneficiary of the insurance contract, the injured party, the consumer or the employee was the defendant; ${ }^{19}$ or (ii) [the exclusive jurisdiction provisions of] Section 6 of Chapter II. ${ }^{20}$

Rather, the most notable change is the elimination of exequatur. ${ }^{21}$ As Article 39 of the Brussels I Recast provides, 'A judgment given in a Member State which is enforceable in that Member State shall be enforceable in the other Member States without any declaration of enforceability being required.' 22 The existence of such a judgment 'shall carry with it by operation of law the power to proceed to any protective measures which exist under the law of the Member State addressed,' subject only to the provision of an authentic copy of the judgment and a certificate from the court of origin certifying that the judgment is enforceable there. ${ }^{23}$ However, the judgment debtor may apply for refusal of enforcement based on one of the specified grounds for non-enforcement and, pending the determination of such an application, the court in which enforcement is sought may limit enforcement proceedings to protective measures, condition enforcement on provision of security, or suspend enforcement proceedings in whole or in part. ${ }^{24}$ In certain specialised areas of EU law, exequatur had already been abolished. ${ }^{25}$ But implementing this change for judgments in civil and commercial matters more generally is an important step toward facilitating the enforcement of foreign judgments within the EU, and

19. These provisions are intended to protect parties assumed to be relatively weak. See Bogdan, above n. 7, at 53 (noting that the equivalent special jurisdictional provisions in the Brussels I Regulation are intended 'to protect the weaker party (the person claiming insurance benefits, the consumer, the employee) against being sued in other Member States than his own, while at the same time giving the same weaker party the option to sue in his own country even when the defendant is domiciled in another Member State').

20. For example, 'in proceedings which have as their object rights in rem in immovable property [...], the courts of the Member State in which the property is situated' has exclusive jurisdiction. Article 24(1) of Brussels I Recast.

21. See F. Cadet, 'Le nouveau règlement Bruxelles / ou l'itinéraire d'un enfant gâté', 140 Journal du Droit International 765, at 768 (2013) ('La suppression de l'exequatur constituait la mesure-phare proposée par la Commission').

22. Article 39 of Brussels I Recast.

23. Articles 40 and 42 of Brussels I Recast.

24. Articles 44 and 46 of Brussels I Recast.

25. See European Commission, Impact assessment accompanying the proposal for a regulation of the European Parliament and of the Council on jurisdiction and the recognition and enforcement of judgments in civil and commercial matters (recast), SEC(2010) 1547 final, at 15 (hereinafter Impact Assessment) (noting abolition of exequatur in Regulation 805/2004 establishing a European enforcement order for uncontested claims, Regulation 1896/2006 creating a European Order for Payment Procedure, Regulation 861/2007 creating a European Small Claims Procedure, and Regulation 4/2009 on jurisdiction, applicable law, recognition and enforcement of decisions and cooperation in matters relating to maintenance obligations). 
an expression of faith in a multilateral system of private international law.

\subsection{US Law and New Grounds for Refusal}

On the other side of the Atlantic, things have been moving in a different, more sceptical direction that is less welcoming to foreign judgments. In the US, state law (not federal law) generally provides the rules governing the enforcement of foreign country judgments. For many years, the most common approach among US states was legislation based on the Uniform Foreign Money-Judgments Recognition Act, which was approved by the National Conference of Commissioners on Uniform State Laws (Uniform Law Commission) in 1962 (1962 Act). The 1962 Act has a general rule in favour of recognition and enforcement of foreign country judgments, followed by three mandatory and six discretionary grounds for refusal:

(a) A foreign judgment is not conclusive if

(1) the judgment was rendered under a system which does not provide impartial tribunals or procedures compatible with the requirements of due process of law;

(2) the foreign court did not have personal jurisdiction over the defendant; or

(3) the foreign court did not have jurisdiction over the subject matter.

(b) A foreign judgment need not be recognized if

(1) the defendant in the proceedings in the foreign court did not receive notice of the proceedings in sufficient time to enable him to defend;

(2) the judgment was obtained by fraud;

(3) the ... [claim for relief] on which the judgment is based is repugnant to the public policy of this state;

(4) the judgment conflicts with another final and conclusive judgment;

(5) the proceeding in the foreign court was contrary to an agreement between the parties under which the dispute in question was to be settled otherwise than by proceedings in that court; or (6) in the case of jurisdiction based only on personal service, the foreign court was a seriously inconvenient forum for the trial of the action. ${ }^{26}$

In 2005, however, the Uniform Law Commission adopted a new uniform act to replace the 1962 Act: the Uniform Foreign-Country Money Judgments Recognition Act of 2005 (2005 Act). The 2005 Act adds two grounds for refusal not contained in the 1962 Act, providing that a court need not recognise a foreign-country judgment if:

(7) the judgment was rendered in circumstances that raise substantial doubt about the integrity of

26. Sections 3 and 4 of Uniform Foreign Money-Judgments Recognition Act of 1962 (1962). Sections 481 and 482 of the Restatement (Third) of Foreign Relations Law of the United States attempts to restate the common law of foreign judgment enforcement, and it is for the most part consistent with the 1964 Act. the rendering court with respect to the judgment; or

(8) the specific proceeding in the foreign court leading to the judgment was not compatible with the requirements of due process of law. ${ }^{27}$

This change invites US judges to more closely scrutinise the specific foreign country court proceedings leading to a judgment. US judges are still barred - as they were under the 1962 Act - from recognising or enforcing a foreign country judgment if it 'was rendered under a judicial system that does not provide impartial tribunals or procedures compatible with the requirements of due process of law. ${ }^{128}$ As the comments to the 2005 Act explain, this provision 'requires the forum court to deny recognition to the foreign-country judgment if the forum court finds that the entire judicial system in the foreign country where the foreign-country judgment was rendered does not provide procedures compatible with the requirements of fundamental fairness' - in other words, it focuses on 'the foreign country's judicial system as a whole. ${ }^{29}$ Traditionally, the failure of due process in a particular case has not been sufficient to establish an exception. ${ }^{30}$ Nevertheless, a growing number of US states are enacting legislation based on the $2005 \mathrm{Act}$, and today there are already more 2005 Act states than 1962 Act states. ${ }^{31}$ Thus, the 2005 Act and its new case-specific grounds for refusal are rapidly becoming the norm in US law.

***

27. Section 4(c) of 2005 Act. Moreover, in 2005, the American Law Institute adopted a proposed federal statute on the recognition and enforcement of foreign judgments that included a mandatory version of the 2005 Act's judicial integrity exception. See American Law Institute, Recognition and Enforcement of Foreign Judgments: Analysis and Proposed Federal Statute (2006), at Section 5(a)(ii) (barring recognition or enforcement if 'the judgment was rendered in circumstances that raise substantial and justifiable doubt about the integrity of the rendering court with respect to the judgment in question') (hereinafter ALI Proposed Statute).

28. Section 4(b)(1) of 2005 Act. See also Section 4(a)(1) of 1962 Act.

29. Section 4, comment 11, of 2005 Act.

30. See Section 4 of 1962 Act (providing systemic but not case-specific due process exception). However, based on a review of US court decisions, one scholar has concluded that even when courts apply the systemic due process standard, they in fact tend to consider case-specific factors. See P. B. Stephan, 'Unjust Legal Systems and the Enforcement of Foreign Judgments', in P.B. Stephan (ed.), Foreign Court Judgments and the United States Legal System (forthcoming).

31. The US Virgin Islands and fifteen states have legislation based on the 1962 Act: Alaska, Connecticut, Florida, Georgia, Maine, Maryland, Massachusetts, Missouri, New Jersey, New York, North Dakota, Ohio, Pennsylvania, Texas and Virginia. However, two of these states - Massachusetts and Virginia - have introduced pending legislation based on the 2005 Act. See <www.uniformlaws.org/LegislativeFactSheet.aspx? title=Foreign \%20Money\%20Judgments\%20Recognition\%20Act> (last visited 4 March 2014). The District of Columbia and eighteen states have adopted legislation based on the 2005 Act: Alabama, California, Colorado, Delaware, Hawaii, Idaho, Illinois, Indiana, Iowa, Michigan, Minnesota, Montana, Nevada, New Mexico, North Carolina, Oklahoma, Oregon, Washington. In addition, legislation based on the 2005 Act has been introduced in Massachusetts, Mississippi and Virginia. See $<$ www.uniformlaws.org/LegislativeFactSheet.aspx?title=Foreign-Country\%20Money\%20Judgments\%20Recognition\%20Act> (last visited 4 March 2014) 
Based on this comparison of the evolution of the law on the two sides of the Atlantic, it is not unfair to characterise the EU as increasingly faithful and the US increasingly sceptical about a multilateral private international law approach that favours the enforcement of foreign judgments. Mais il ne faut pas exagérer. The history leading up to the Brussels I Recast revealed doubts - some of which will be explored below - that suggest that EU faith is not as uniform as the analysis so far might suggest. To give one example, in addition to the abolition of exequatur, the Commission's original proposal for the Brussels I Recast would not have left any possibility of opposing recognition (proposed Article 38) and eliminated public policy as a ground for refusing enforcement (proposed Article 43). ${ }^{32}$ There were strong objections to these proposals from some scholars and member states. ${ }^{33}$ In the end, these further changes were not made. It would thus seem fair to conclude that when it comes to foreign judgments, faith in private international law may run more deeply at the Commission than in the EU at large. Still, the picture is different than in the US, where there is no concerted move toward a more welcoming approach to foreign country judgments to react against in the first place.

\section{Trust/Distrust}

What explains these differences between the EU and the US? One answer seems obvious at first glance: whereas the Brussels I Regulation and the Brussels I Recast deal with the enforcement of judgments internal to the EU (that is, the enforcement in EU member states of the judgments of other EU member states), the 1962 Act and the 2005 Act deal with the enforcement of judgments external to the US (that is, the enforcement in the US of judgments of foreign countries in general). It is natural - the argument would go - for the EU to be heading toward an internal approach that is more like the US internal approach, which is based on constitutional full faith and credit. To use a concept that is explicitly invoked in EU private international law, 'mutual trust' is the key, and that trust is surely stronger among EU members than between the US and the rest of the world.

\subsection{Mutual Trust, Internal Judgments, and External Judgments}

In the EU, the principle of mutual trust has played an animating role in private international law since at least the early 1990s. In Sonntag v. Waidmann, a 1993 case before the European Court of Justice, Advocate General Darmon stated in his opinion that ' $[\mathrm{t}]$ he principle of the recognition of judgments is based on the Member States' mutual trust in their respective legal systems and judicial institutions. This trust allows the Member States to waive their internal rules on the recognition and enforcement of foreign judgments. ${ }^{34}$ Reinforcing this understanding, the Brussels I Recast explicitly links the abolition of exequatur to mutual trust:

Mutual trust in the administration of justice in the Union justifies the principle that judgments given in a Member State should be recognised in all Member States without the need for any special procedure.... As a result, a judgment given by the courts of a Member State should be treated as if it had been given in the Member State addressed. ${ }^{35}$

Likewise, in the US, both of the new case-specific exceptions added by the 2005 Act have been justified in terms of 'mutual trust' - or lack thereof - even though the exact words are not used. As the Study Report for the 2005 Act pointed out regarding its new case-specific due process exception, '[t]here is less expectation that foreign courts will follow procedures comporting with U.S. notions of due process and jurisdiction or that they will apply substantively tolerable laws, and there may be suspicions of unfairness or fraud. ${ }^{36}$ The Reporter's Notes to a draft of the 2005 Act also noted support for the 2005 Act's case-specific judicial integrity exception based on the perception that 'bribery and other forms of judicial misconduct can be a real issue with regard to
32. European Commission, Proposal for a Regulation of the European Parliament and of the Council on Jurisdiction and the recognition and enforcement of judgments in civil and commercial matters (recast), COM(2010) 748 final, 2010/0383 (COD) (hereinafter Brussels I Recast Proposal). The proposal did add, however, a limited right for a judgment debtor to 'apply for a refusal of recognition or enforcement of a judgment where such recognition or enforcement would not be permitted by the fundamental principles underlying the right to a fair trial' (Article 46) and it preserved the public policy ground for certain specified defamation and collective redress claims (Article 37).

33. See X.E. Kramer, 'Cross-Border Enforcement and the Brussels I-Bis Regulation: Towards a New Balance between Mutual Trust and National Control Over Fundamental Rights,' 60 Netherlands International Law Review 343, at 365 (2013) (noting that the proposed removal of the public policy exception was 'extensively debated' and arguing that '[t]he protection of public policy is to be regarded as a matter of the rule of law and has always been regarded as a necessary safety valve in private international law.'
34. Opinion of Advocate General Darmon in Case C-172/91, Sonntag v. Waidmann [1993] ECR I-1963, at para. 71-72.

35. Recital 26 of Brussels I Recast. See also Pamela Kiesselbach, at 8 (explaining that the proposal to abolish exequatur 'is premised upon the assumption of a high level of mutual trust and confidence in the maturity of judicial systems across the EU'); X. Kramer, 'Procedure Matters: Construction and Deconstructivism in European Civil Procedure', 33 Erasmus Law Lectures, 33 (2012), at 18 ('Based on this pillar [mutual trust], the European Commission wishes to abolish the permission of courts for the enforcement of judgments rendered in another EU Member State. The idea is that if there is full mutual trust, this permission (called exequatur) is no longer required').

36. K. Patchel, 'Study Report on Possible Amendment of the Uniform Foreign Money-Judgments Recognition Act', 25 June 2003, at 26. 
certain foreign country judgments. ${ }^{37}$ The federal statute on the recognition and enforcement of foreign judgments proposed by the American Law Institute in 2005 justified its mandatory judicial integrity exception in similar terms: 'The defense of possible corruption in the rendering court is one that has not traditionally been an explicit ground for nonrecognition or nonenforcement by courts in the United States. However, concerns about corruption in the judiciaries of certain countries and the effect of corruption in the particular case led to inclusion of this additional defense. 38

It is noteworthy that the European Commission has also used lack of mutual trust as a reason for not extending the Brussels regime to non-EU members, raising concerns that 'companies might not always get a fair trial and an adequate protection of their rights before the courts of a third State' and that '[s] uch problems can notably arise in countries where the judiciary cannot be considered to be independent or is riven by corruption. ${ }^{39}$ Similarly, in his opinion in Orusu v. N.B. Fackson and others, Advocate General Léger explained that the EU established the simplified Brussels Convention mechanism for recognition and enforcement in a specific context characterised by mutual trust between the Member States of the Community regarding their legal systems and their judicial institutions. However, the same situation does not necessarily prevail in relations between Member States and non-Contracting States. That is why this mechanism of the Convention applies only to judgments given by courts of a Member State in the context of their recognition and enforcement in another Member State. ${ }^{40}$

\subsection{Assessing the Trust/Distrust Explanation}

The internal/external distinction and its implications for mutual trust surely help explain EU-US differences in the law of foreign judgments. Still, this account is not entirely satisfying. First, if the Brussels I Recast limits its application to a zone of mutual trust by limiting the definition of 'judgment' to a 'judgment given by a court or tribunal of a Member State' (which is assumed to be deserving of trust), ${ }^{41}$ US judgment enforcement law - in theory, at least - also limits its application to a zone of mutual trust by prohibiting enforcement if 'the judgment was rendered under a judicial system that does not provide impartial tribunals or procedures compatible

37. Discussion Draft of 2005 Act, October 2004, at 7. The American Law Institute's commentary on the corruption ground for non-enforcement in its proposed federal statute on foreign judgments also expresses distrust, noting 'concerns about corruption in the judiciaries of certain countries'. The drafters acknowledge that ' $[t]$ he defense of possible corruption in the rendering court is one that has not traditionally been an explicit ground for nonrecognition or nonenforcement by courts in the United States.' But they explain that 'concerns about corruption in the judiciaries of certain countries and the effect of corruption in the particular case led to inclusion of this additional defense'.

38. ALI Proposed Statute, above n. 27, at 60 (comment d on Section 5).

39. Impact Assessment, above n. 25, at 20.

40. Opinion of Advocate-General Léger in Case C-281/02, Owusu v. N.B. Jackson and others [2005] ECR I-1383, at para 144.

41. Article 2(a) of Brussels I Recast. with the requirements of due process of law. ${ }^{42}$ Countries satisfying this systemic due process requirement are assumed to be 'peers' of the US that share its basic principles of procedural fairness. ${ }^{43}$ The judgments of 'non-peer' countries - those that do not meet the systemic due process requirement - cannot be enforced in the US. ${ }^{44}$ But whereas this delineation leads the Brussels I Recast to limit itself to a very narrow set of grounds for non-enforcement, the 2005 Act follows with comparatively broad grounds for non-enforcement that are arguably redundant to the systemic due process ground. For example, issues of fraud or case-specific due process presumably can be dealt with fairly through the rehearing or appellate procedures available in a legal system that provides impartial tribunals and procedures compatible with the requirement of due process of law. ${ }^{45}$ In other words, both EU and US judgment enforcement law seem to limit their scope to a zone of mutual trust, albeit using different methods (limiting to EU members in the Brussels I Recast, limiting to countries with systemic due process in the 2005 Act) - yet US law nevertheless provides broader grounds for nonenforcement. ${ }^{46}$

Second, the Brussels I Recast does not uniformly move in the direction of enhanced mutual trust. As already noted, the Commission proposed eliminating the public policy exception ${ }^{47}$ - but in the end, it was retained. ${ }^{48}$ In addition, prior to the adoption of the Brussels I Recast, the Court of Justice of the European Union (CJEU) (then the European Court of Justice) had interpreted the rule of lis pendens to require a court second seised to stay its proceedings in favour of a court first seised - even where the party commencing litigation in the court first seised did so in bad faith, ${ }^{49}$ where the court second seised appears to have exclusive jurisdiction under a choice-of-court agreement, ${ }^{50}$ or where the duration of

42. Section 4(b)(1) of 2005 Act. I say 'in theory' rather than 'in practice' because observers tend to agree that this systemic due process exception does not appear to be relied upon frequently by US courts to refuse enforcement. See Stephan, above n. 30. This ground for refusal may nevertheless have significant practical effect by discouraging attempts to enforce judgments rendered by courts in countries that obviously fail to meet the systemic due process and impartiality standard - and, indeed, by discouraging attempts to litigate against US defendants in those countries in the first place.

43. See Society of Lloyd's v. Ashenden, 233 F.3d 473, 477 (7th Cir. 2000) (interpreting this provision as requiring that 'the foreign procedures are "fundamentally fair" and do not offend against "basic fairness" ').

44. Section $4(b)(1)$ of 2005 Act.

45. See C.A. Whytock, 'Some Cautionary Notes on the "Chevronization" of Transnational Litigation', 1 Stanford Journal of Complex Litigation 467, at 480-81 (2013).

46. However, it should be noted that it is possible that the public policy ground for refusal contained in the Brussels I Recast could be applied to avoid enforcement in some of the situations covered by various grounds for enforcement that are included in the 2005 Act but not the Brussels I Recast.

47. See Chapter III of Brussels I Recast Proposal, above n. 32.

48. See Article 45(1)(a) of Brussels I Recast (ground for refusal if recognition is 'manifestly contrary to public policy (ordre public) in the Member State addressed')

49. Case 159/02, Turner [2004] ECR I-3565, at para. 31.

50. Case C-116/02, Gasser [2003] ECR I-14693, at para. 54. 
proceedings in the court first seised are excessively long. ${ }^{51}$ In Turner, for example, the CJEU justified these rulings on the basis of mutual trust: ${ }^{52}$

[I]t must be borne in mind that the Convention is necessarily based on the trust which the Contracting States accord to one another's legal systems and judicial institutions. It is that mutual trust which has enabled a compulsory system of jurisdiction to be established, which all the courts within the purview of the Convention are required to respect, and as a corollary the waiver by those States of the right to apply their internal rules on recognition and enforcement of foreign judgments in favour of a simplified mechanism for the recognition and enforcement of judgments....

It is inherent in that principle of mutual trust that, within the scope of the Convention, the rules on jurisdiction that it lays down, which are common to all courts of the Contracting States, may be interpreted and applied with the same authority by each of them....

In so far as the conduct for which the defendant is criticized consists in recourse to the jurisdiction of the court of another Member State, the judgment made as to the abusive nature of that conduct implies an assessment of the appropriateness of bringing proceedings before a court of another Member State. Such an assessment runs counter to the principle of mutual trust....

The Commission expressed the concern that these applications of the lis pendens rule enabled litigation tactics that can cause delay and frustrate valid choiceof-court agreements. ${ }^{53}$ On that basis, Article 31(2) of the Brussels I Recast limits the general lis pendens rule by providing that 'where a court of a Member State on which [a valid choice-of-court agreement] confers exclusive jurisdiction is seised, any court of another Member State shall stay the proceedings until such time as the court seised on the basis of the agreement declares that it has no jurisdiction under the agreement.' By doing so, the Brussels I Recast implicitly limits the principle of mutual trust as enunciated by the CJEU in Gasser and Turner.

Third, even if there is on average more mutual trust among EU members than between the US and other countries, the mutual trust theory does not seem capable of explaining the different directions in which $\mathrm{EU}$ and US law is evolving. On the US side, the mutual trust theory cannot alone explain the sceptical trend in US

51. Gasser, at para. 73 .

52. Turner, at paras. 24,25 and 28. The CJEU used similar reasoning in Gasser. SeeGasser, para. 72.

53. European Commission, Report from the Commission to the European Parliament, the Council and the European Economic and Social Committee on the application of Council Regulation (EC) No. 44/2001 on jurisdiction and the recognition and enforcement of judgments in civil and commercial matters, $\operatorname{COM}(2009) 174$ final, at 6 . law. To do so, it would need an underlying theory to explain why US trust would be on a decline rather than simply why it is perhaps lower than within the EU. ${ }^{54}$ And on the EU side, the mutual trust theory raises a puzzle: foreign judgment enforcement is being facilitated notwithstanding the recent enlargement of $\mathrm{EU}$ membership. In 2004, ten new countries joined the EU: the Czech Republic, Estonia, Cyprus, Latvia, Lithuania, Hungary, Malta, Poland, Slovakia and Slovenia - the largest single enlargement of the EU. In 2007, Bulgaria and Romania joined, and in 2013, Croatia joined, bringing the number of member states to twenty-eight. ${ }^{55}$ Although each country admitted to the EU must satisfy rigorous conditions for membership, and although the European Convention on Human Rights and the EU Charter of Fundamental Rights provide minimum standards of fair trial, corruption is widely viewed to be a significant problem in EU member states ${ }^{56}$ and, as one expert suggests, enlargement has arguably exacerbated these concerns:

The issue of corruption is a sensitive one in the EU, and is usually avoided in the legislative discussions on private international law. But the existence of corruption in general is acknowledged, and was put on the political agenda. Recent reports from Transparency International and the EU have revealed that corruption is a major problem in many member states, and that it has increased over the past few years. Corruption exists in every member state, but the reports make clear that the expansion of the EU to countries with weaker institutions requires serious attention. In this light, [assertions] on mutual trust may be a little too optimistic. ${ }^{57}$

For these reasons, the mutual trust theory seems unable to explain the directions of change in the EU and the US. In the EU, enforcement is becoming more streamlined notwithstanding enlargement which, other things being equal, would seem to challenge rather than strengthen mutual trust. In the US, mutual trust vis-à-vis the rest of the world might be changing - but if so, why? Therefore, mutual trust leaves much to be desired as an explanation for growing EU faith and growing US scepticism in foreign judgment enforcement. Are there better explanations?

54. The answer is not obvious, although one possibility will be explored below. See Section 3 on politics.

55. See <http://ec.europa.eu/enlargement/policy/from-6-to-28-members/ index_en.htm> (last visited 16 June 2014).

56. See European Commission, EU Anti-Corruption Report, COM(2014) 38 final, available at <http://ec.europa.eu/dgs/home-affairs/what-we-do/ policies/organized-crime-and-human-trafficking/corruption/anti-corruption-report/index_en.htm> (last visited 16 June 2014).

57. X.E. Kramer, 'Approaches to Jurisdiction and Foreign Judgments and the International Fight against Corruption', in International Law and the Fight against Corruption (2012) 99, at 139. See also Rafael Arenas Garcia, 'Abolition of Exequatur: Problems and Solutions', 12 Yearbook of Private International Law 351, 372 (2010) ('[M]utual trust is a legal obligation, but it can also be seen as a fact. In other words: the authorities of one Member State must trust the authorities of the other Member States; but do they really trust them?'). 


\section{Governance/Rights}

One alternative (or complementary) account is that the EU's apparently growing faith in private international law is a result of an increasingly strong focus on private international law's governance functions, leading to efforts to facilitate judgment enforcement such as the abolition of exequatur. Meanwhile, so the theory would go, the US remains focused on how private international law affects individual rights - in particular, the rights of judgment debtors - leading it to take a more sceptical approach with robust grounds of refusal to protect against the enforcement of judgments that procedurally or substantively would violate the rights of the judgment debtor.

\subsection{The Concept of Governance Values and Rights Values}

This explanation posits two types of values that manifest themselves to varying degrees in the law governing the enforcement of foreign country judgments, and indeed private international law more generally: governance values and rights values. ${ }^{58}$ Governance values focus on policies facilitating, guiding or restraining collective activity. ${ }^{59}$ These values have implications that extend beyond the parties to particular disputes. ${ }^{60} \mathrm{Gov}-$ ernance values include efficiency, which is concerned with avoiding the expenditure of societal resources to re-litigate issues that have already been litigated, and with reducing transaction costs in transnational business. ${ }^{61}$ Efficiency is closely related to the principle of repose, which emphasises 'the need to put to rest quar-

58. This section builds on my prior work distinguishing between governance-oriented analysis and litigant-oriented analysis of transnational law. See Whytock (2009), above n. 9, at 115-22 (available at <http:// ssrn.com/abstract=923907>); C.A. Whytock, 'Transnational Judicial Governance', 2 St. John's Journal of International and Comparative Law 55 (2012) (available at <http://ssrn.com/abstract=2043343>). I have previously applied this distinction to evaluate the relationship between the forum non conveniens doctrine and the law of foreign judgment enforcement, see C.A. Whytock and C.B. Robertson, 'Forum Non Conveniens and the Enforcement of Foreign Judgments', 111 Columbia Law Review 1444 (2011) (available at <http://ssrn.com/ abstract=1895011>) and to international choice of law, see C.A. Whytock, 'Myth of Mess? International Choice of Law in Action', 84 New York University Law Review 719 (2009) (available at <http://ssrn.com/ abstract=1257096>).

59. See R.O. Keohane, Power and Governance in a Partially Globalized World (2002), at 245-46 (defining governance as 'the processes and institutions, both formal and informal, that guide and restrain [...] collective activit[y]').

60. See Whytock (2009), above n. 8, at 31

61. See R. Michaels, 'Recognition and Enforcement of Foreign Judgments', Max Planck Encyclopedia of Public International Law (available at $<$ www.mpepil.com $>$ ) (noting that 'the general public has an interest in avoiding resources spent on re-litigation and in international decisional harmonies'); A.T. von Mehren and D.T. Trautman, 'Recognition of Foreign Adjudications: A Survey and a Suggested Approach', 81 Harvard Law Review 1601, at 1603-1604 (1968) (noting 'desire to avoid the duplication of effort and consequent waste involved in reconsidering a matter that has already been litigated'). See also J. Lookofsky and K. Hertz, EU-PIL: European Union Private International Law in Contract and Tort (2009), at 135 (noting importance of foreign judgment enforcement to 'promote efficiency and economy in international business'). rels and disputes that have arisen so that the energies of individuals and the resources of society can be devoted to more constructive tasks. ${ }^{62}$ Governance values also include certainty and predictability, which help 'to establish the security of contracts, promote commercial dealings, and generally further the rule of law among states that are interdependent as well as independent. ${ }^{63}$ Comity is another governance value, according to which one country gives domestic effect to a judgment of another country not out of legal obligation but out of respect for a legally equal sovereign, thus 'fostering stability and unity in an international order. ${ }^{.64}$

Private international law also implicates rights. Rights values focus on justice for particular litigants in particular cases. These values emphasise what Arthur von Mehren calls the 'principle of correctness,' which 'expresses the concern that legal justice, as understood by the society in both substantive and procedural terms, be done. ${ }^{65} \mathrm{~A}$ similar principle has been expressed in the choice-of-law context as the principle of 'material justice,' which is concerned with obtaining a 'proper result, i.e. a result that produces the same quality of justice in the individual case as is expected in fully domestic, nonconflicts cases. ${ }^{.66}$ Rights values also entail the 'concern to protect the successful litigant, whether plaintiff or defendant, from harassing or evasive tactics on the part of his previously unsuccessful opponent. ${ }^{67}$ In the judgment enforcement context, rights values may account for both the interests of judgment debtors against the enforcement of judgments that are inconsistent with their substantive or procedural rights, and the interests of judgment creditors in the enforcement of judgments under which they have rights.

Of course, governance values and rights values are not mutually exclusive. Protecting rights in particular cases can advance broader governance values, and governance values like efficiency and predictability can benefit individual litigants. As a result, there can certainly be debate

62. A.T. von Mehren, 'Recognition and Enforcement of Foreign Judgments - General Theory and the Role of Jurisdictional Requirements', 167 Recueildes Cours, at 20-22 (1981).

63. A.F. Lowenfeld, 'International Litigation and the Quest for Reasonableness: General Court on Private International Law', 245 Recueil des Cours, at 109 (1994). See also Von Mehren and Trautman, above n. 61, at 1603-1604 (noting 'interest in fostering stability and unity in an international order in which many aspects of life are not confined to any single jurisdiction [...].'); Michaels, above n. 61, at 2 (referring to 'transnational legal certainty' as a value underlying the enforcement of foreign judgments).

64. See Von Mehren and Trautman, above n. 61, at 1603-1604. See also Michaels, above n. 61, at 2 ('Dutch authors, in particular Voet and Huber, developed [the principle of] comity, defined much later by the United States Supreme Court in [Hilton v. Guyot,] a decision denying recognition to a French judgment as "neither a matter of absolute obligation on the one hand nor of mere courtesy and good will .... it is the recognition which one nation allows within its territory to the legislative, executive or judicial acts of another [...]."').

65. Von Mehren, above n. 62, at 20-22.

66. S.C. Symeonides, 'American Choice of Law at the Dawn of the 21st Century', 37 Willamette Law Review 1, 69 (2001). Material justice is contrasted with 'conflicts justice', which seeks 'the proper law, i.e., the law that has the most pertinent connections to the case but without regard to the quality of the result it produces'. Id.

67. Von Mehren and Trautman, above n. 61, at 1603-1604. 
over the precise content of governance values and rights values. Nor can these two sets of values be simultaneously maximised. ${ }^{68}$ This means that different approaches to the enforcement of foreign judgments will necessarily entail different tradeoffs between governance values and rights values.

\subsection{Governance Values and Rights Values in EU Law and US Law}

In EU law, the tradeoffs appear to favour governance values, and in US law they appear to favour rights values. ${ }^{69} \mathrm{~A}$ comparison of the grounds for refusing enforcement provide a tentative indication of these differing tradeoffs. First - and most simplistically - the Brussels I Recast has fewer grounds for refusal than the 2005 Act. With fewer grounds for refusal, the Brussels I Recast promises to enhance efficiency by reducing the need for re-litigation and to increase certainty and predictability by helping to ensure enforceability throughout the EU. On the other hand, it provides relatively limited explicit protections for the rights of judgment debtors (although the public policy ground for refusal provides a possible avenue for assuring that a foreign judgment that resulted from a violation of fundamental procedural rights will not be enforced). ${ }^{70}$ With more numerous grounds for refusal, the 2005 Act strikes a different tradeoff: the US approach might more generously protect the rights of judgment debtors, but it risks creating additional litigation costs at the enforcement stage, increasing the likelihood of repeat litigation on the merits if enforcement is refused, and decreasing predictability.

Second, beyond the simple difference in the number of grounds for non-enforcement, there are qualitative differences that provide a further indication of the different tradeoffs struck in the EU and the US. For example, the particular grounds for non-enforcement included in the 2005 Act but not in the Brussels I Recast reflect a

68. See Von Mehren, above n. 62, at 22 ('Embracing one [principle] to the complete exclusion of the other would be intolerable. Assigning an absolute value to correctness would create an enormous social and economic burden, unduly reward the disputatious, and undermine the security of transactions and relations that is essential if economic and social life are to go forward. On the other hand, giving full scope to the principle of repose would require that full and absolute finality be given to every determination made by an adjudicator of first instance. But the experience of failure of justice in individual cases is universal; a system of justice that, in the name of repose, denied in every case a second chance would be perceived as fundamentally unjust. No universal or final solution can be provided to the question of the proper accommodation between the principles of correctness and repose. The values ultimately at stake - those of ideal justice and of practical justice - are incommensurable; in the absence of a superior principle in terms of which accommodation can be effected, a tension persists between the two principles and no solution can ever be entirely stable nor demonstrably correct.')

69. It was not always the case that European private international law linked itself to governance values, and least in the realm of choice of law. See Muir-Watt, 'European Integration, Legal Diversity and the Conflict of Laws', 9 Edinburgh Law Review 6, at 14-15 (2005).

70. In fact, to preserve a 'fair trial' ground for refusal even with the elimination of the public policy ground, the Commission included in its proposal a new ground for refusal that would apply where 'recognition or enforcement would not be permitted by the fundamental principles underlying the right to a fair trial.' Article 46(1) of Brussels I Recast Proposal. rights orientation in US law that carries with it potential tradeoffs against the governance values of efficiency and predictability. The 2005 Act's systemic and casespecific due process exception, as well as its fraud, inconvenient forum, and lack-of-integrity exceptions, are all aimed at protecting the rights of judgment debtors, but increase uncertainty about whether particular judgments will be enforced and can lead to costly litigation at the enforcement stage. Here again, the differences should be kept in perspective, because the public policy ground for refusal in the Brussels I Recast can be understood as encompassing some of the grounds explicitly covered only by the 2005 Act - such as fraud or lack of judicial integrity - at least insofar as these circumstances indicate a violation of a judgment debtor's fair trial rights. ${ }^{71}$ Nevertheless, the explicit enumeration of these additional grounds in the 2005 Act does suggest a more rights-oriented US approach. Moreover, the Brussels I Recast's grounds for non-enforcement are all mandatory. ${ }^{72}$ In contrast, under US law, grounds for non-enforcement are discretionary, except for the first three, which are mandatory: the foreign judicial system does not provide impartial tribunals or procedures compatible with the requirements of due process, lack of personal jurisdiction, and lack of subject matter jurisdiction. ${ }^{73}$ Discretion both allows judges to balance the rights of the parties in particular cases (which accommodates rights values), but it also creates more potential for unpredictability and inconsistency (which can compromise governance values). From this perspective, too, EU law appears more governance-oriented than US law. A dynamic comparison of trends is consistent with this description of the different tradeoffs between governance values and rights values in EU law and US law. For example, the EU's abolition of exequatur can be understood as a shift away from rights values. As Peter Stone argues, '[t]he effect of the change ... will usually be to reduce from an already low level the protection which a defendant can obtain from the courts of his own country. ${ }^{, 74}$ Similarly, Andrew Dickinson voices the concern that exequatur provides significant protection against fraudulent enforcement proceedings. ${ }^{75}$ Moreover, according to one recent analysis, the jurisprudence

71. X.E. Kramer, 'Cross-Border Enforcement in the EU: Mutual Trust versus Fair Trial? Towards Principles of European Civil Procedure', 2 International Journal of Procedural Law 202, at 219 (2011) ('A safety net for the violation of fair trial principles is provided [by the Brussels I Recast] at the enforcement level through the ground of refusal relating to public policy'). However, this function of the public policy exception may be limited by the principle that this ground for refusal 'is intended to be a last resort in very exceptional situations only'. Bogdan, above n. 7, at 73.

72. See Article 46 of Brussels I Recast (providing that 'the enforcement of a judgment shall be refused' where one of the grounds for non-recognition is found to exist) (emphasis added)

73. Compare Section 4(b) of 2005 Act ('[a] court of this state may not recognize [...].') with Section 4(c) of 2005 Act ('[a] court of this state need not recognize [...].') (emphasis added).

74. P. Stone, EU Private International Law (2nd edn. ) (2010), at 256.

75. A. Dickinson, 'Surveying the Proposed Brussels I bis Regulation - Solid Foundations But Renovation Needed', 12 Yearbook of Private International Law 256 (2d edn.) 247, at 267 (2010). 
of the European Court of Human Rights 'clearly recognizes the value of exequatur or similar proceedings for the protection of human rights of the judgment debtor. ${ }^{76}$ But others note that exequatur rarely resulted in non-enforcement anyway, and argue that in any event the ability of a judgment debtor to apply for refusal of enforcement and appeal a decision to deny that application renders the elimination of exequatur inconsequential from a rights perspective. ${ }^{77}$ For example, Peter Hay argues that 'abolition of the exequatur streamlines the recognition process, but ... does not change it much substantively.' ${ }^{78}$ Similarly, Samuel Baumgartner argues that 'the abolition of the declaration of enforceability sounds like a bolder move than it really is. ${ }^{79}$ But even if this move does not substantially undermine rights values, it still indicates a stronger EU emphasis than before on governance values. In fact, governance values are declared in the Brussels I Recast itself. As its preamble notes, it is essential to eliminate '[c]ertain differences between national rules governing jurisdiction and recognition of judgments [that] hamper the sound operation of the internal market' and to put in place rules 'to ensure rapid and simple recognition and enforcement of judgments, ${ }^{80}$ in furtherance of the objective of free circulation of judgments in civil and commercial matters. ${ }^{\text {}} 1$ Regarding exequatur specifically, the preamble explains that 'the aim of making cross-border litigation less time-consuming and costly justifies the abolition of the declaration of enforceability prior to enforcement in the Member State addressed. ${ }^{82}$ As Samuel Baumgartner notes, whereas '[ $t]$ he purpose of the Brussels Convention of 1968 was primarily to harmonize and to some extent to liberalize the recognition of judgments from other member states,' the goal since 1999 has been 'to achieve the free movement of judgments' - which is a distinctly governance-oriented goal. ${ }^{83}$ Conversely, in the US, the shift toward new casespecific grounds for non-enforcement promises to provide better protections of the rights of judgment debtors. In this sense, this trend is toward a greater emphasis on rights values. On the other hand, this trend runs the risk of undermining the governance values of efficiency, predictability and comity if these new grounds end up leading to increased litigation at the

76. T. Schilling, 'The Enforcement of Foreign Judgments in the Jurisprudence of the European Court of Human Rights', at n. 91 (January 2012) (available at <http://works.bepress.com/theodor_schilling/9>).

77. See B. Hess, 'Note on the Proposal for a Regulation of the European Parliament and of the Council on Jurisdiction and the Recognition and Enforcement of Judgments in Civil and Commercial Matters (Recast)', PE 453.201 (2011), at 8

78. P. Hay, 'Notes on the European Union's Brussels-I "Recast" Regulation: An American Perspective', European Legal Forum, at 6 (January/February 2013) (available at <http://ssrn.com/abstract=2267816>).

79. S.P. Baumgartner, 'Changes in the European Union's Regime of Recognizing and Enforcing Foreign Judgments and Transnational Litigation in the United States', 18 Southwestern Journal of International Law (2012) (available at <http://ssrn.com/abstract=2019067>).

80. Preamble 4 of Brussels I Recast.

81. Id., preamble 6

82. Id., recital 26

83. Baumgartner, above n. 79 , at 25 judgment enforcement stage of proceedings. Commentators in the US are not unaware of these implications for governance values. ${ }^{84}$ For example, the American Law Institute rejected a case-specific due process exception in its proposed federal statute on foreign country judgments, explaining that '[s]uch a detailed inquiry into the foreign judgment is inconsistent with the proenforcement philosophy of [the 1962] Act. ${ }^{95}$ Similarly, the US Court of Appeals for the Seventh Circuit has expressed the concern that a case-specific approach would be inconsistent with providing a streamlined, expeditious method for collecting money judgments rendered by courts in other jurisdictions' and 'would in effect [allow] a further appeal on the merits ... thus converting every successful multinational suit for damages into two suits .... ${ }^{86}$ But these concerns ultimately have not carried the day, as suggested by the increasingly widespread adoption of the 2005 Act by US states. ${ }^{87}$

\subsection{Assessing the Governance/Rights Explanation}

Like the trust/distrust account, the governance/rights account of EU-US differences is not entirely satisfactory. First, the US approach is perhaps more accurately understood as focusing not on rights in general but rather on the rights of judgment debtors. Broader grounds for refusing enforcement may help protect judgment debtors, but in practice they can make enforcement more difficult, time consuming and costly - in some cases, perhaps to the extent that the value of the judgment does not justify the effort. Second, the EU approach does take into account rights. It facilitates enforcement at least partly based on the European right to court access. 'The abolition of exequatur has ... been justified by the desire to enhance access to justice and the right to an effective remedy, as guaranteed by Article 47 of the EU Charter and Articles 6 and 13 of the ECHR. ... From the perspective of the judgment creditor, the interests are evidently to enforce his rights as a result of a judgment in an efficient way. ${ }^{88}$ It also is attentive to the rights of judgment debtors, albeit perhaps not as expan-

84. Interestingly, this movement in US foreign country judgment enforcement law is not unlike an earlier evolution of US choice-of-law principles. See Symeonides, above n. 66, at 10 (describing shift in US choice of law from an emphasis on legal certainty, conflicts justice, and uniformity at the beginning of the twentieth century to a greater emphasis today on material justice and flexibility). However, whereas the US law of foreign judgment enforcement appears to be continuing to move in this direction, in choice of law the trend may be starting to reverse itself. $I d$. at 11

85. See Section 5, comment c, of ALI Proposed Statute.

86. Society of Lloyd's v. Ashenden, 233 F.3d 473, 477 (7th Cir. 2000).

87. See above n. 31.

88. X.E. Kramer, 'Cross-Border Enforcement and the Brussels I-Bis Regulation: Towards a New Balance between Mutual Trust and National Control Over Fundamental Rights', 60 Netherlands International Law Review 343, 367 (2013). 
sively as the US approach. ${ }^{89}$ Unlike the 2005 Act, the Brussels I Recast does not have an exception that explicitly applies when there are defects in the particular proceedings leading to a judgment. However, '[a] safety net for the violation of fair trial principles is provided [by the Brussels I Recast] at the enforcement level through the ground of refusal relating to public policy. ${ }^{90}$ And it should not be forgotten that the Brussels I Recast itself highlights the rights of judgment debtors: 'The direct enforcement in the Member State addressed of a judgment given in another Member State without a declaration of enforceability should not jeopardise respect for the rights of the defence. ${ }^{91}$

There are many complexities and nuances, and of course both governance values and rights values influence both EU law and US law. But overall the analysis suggests that the EU and US have struck significantly different tradeoffs between these two sets of values in the law governing the enforcement of foreign country judgments. In comparison to each other, the EU seems to emphasise governance values more strongly and the US seems to emphasise rights values more strongly in the law of foreign judgments. Nevertheless, this account is incomplete because it does not explain the source of these different tradeoffs.

\section{Politics}

So where does the emphasis on governance values or rights values come from? One might argue legal culture. But US legal culture is more multifaceted than often assumed, and the legal cultures of EU members remain too diverse for legal culture to adequately explain the evolution of EU law. ${ }^{92}$ To explain EU-US differences in the law of foreign country judgments, it seems necessary to look to politics.

From the beginning, the EU's 'constitution' - its foundational treaties - established a political mandate to facilitate the enforcement of judgments within the EU. This mandate is explicitly linked to the achievement of the EU common market. Article 220 of the Treaty of Rome establishing the European Economic Community in 1958 called for negotiations on the recognition and enforcement of court judgments within the EU, and this led to the adoption of the Brussels Convention in

Through the public policy ground for refusal, for example, EU Member States may decline enforcement of a judgment when enforcement would violate the judgment debtor's rights under the EU Charter of Fundamental Rights or the European Convention on Human Rights. A. Dickinson, 'Surveying the Proposed Brussels I bis Regulation - Solid Foundations but Renovation Needed', 12 Yearbook of Private International Law 247, at 260 (2010)

90. Kramer, above n. 71, at 219

91. Recital 29 of Brussels I Recast.

92. See F. Blobel and P. Spath, 'The Tale of Multilateral Trust and the European Law of Civil Procedure', 30 European Law Review 528, at 541 (2005) (observing that within the EU 'national procedures, the training, legal education and professional self-perception of lawyers and judges in particular, as well as their respective legal cultures still vastly differ').
$1968 .{ }^{93}$ In 1997, the Treaty of Amsterdam amended the Treaty Establishing the European Community (which was later renamed by the 2007 Lisbon Treaty as the Treaty on the Functioning of the European Union (TFEU)) to add provisions on judicial cooperation in civil matters authorising measures aimed at '(a) improving and simplifying ... the recognition and enforcement of decisions in civil and commercial cases. ${ }^{94}$ Title V, Chapter 3 of the TFEU, is dedicated to Judicial Cooperation in Civil Matters. In it, Article 67 provides that '[t]he Union shall constitute an area of freedom, security and justice with respect for fundamental rights and the different legal systems and traditions of the Member States' and '[t]he Union shall facilitate access to justice, in particular through the principle of mutual recognition of judicial and extrajudicial decisions in civil matters.' Article 81 provides that '[t]he Union shall develop judicial cooperation in civil matters having cross-border implications, based on the principle of mutual recognition of judgments ...' Building on this political mandate, the European Council prioritised mutual recognition of judgments, including in its 1999 Tampere meetings. ${ }^{95}$ In 2001, the EU Council called for revision of the Brussels I Regulation. ${ }^{96}$ In its 2010 Stockholm Programme, the European Council renewed the call, ${ }^{97}$ and the European Commission responded with its Brussels I Recast proposal. ${ }^{98}$

The politics of foreign country judgments are different in the US. The US has no official political mandate regarding foreign country judgments that is equivalent to the EU's mandate regarding the judgments of EU member states' courts. But the politics are there, and they push in the other direction. The US Chamber of Commerce, through its Institute for Legal Reform, has been at the forefront of efforts to reform US law on foreign country judgment enforcement. The US Chamber of Commerce has considerable political influence in the US. It is 'the world's largest business organization representing the interests of more than 3 million businesses of all sizes, sectors, and regions. ${ }^{99}$ It 'advocate[s] for pro-business policies' using a 'nationally recognized team of lobbyists, communicators, and policy experts. ${ }^{100}$ Through reports and outreach to judges,

93. Article 220 provided: 'Member States shall, in so far as necessary, engage in negotiations with each other with a view to ensuring for the benefit of their nationals ... the simplification of the formalities governing the reciprocal recognition and execution of judicial decisions and of arbitral awards.'

94. Article 65 of the Treaty Establishing the European Community (Consolidated Version).

95. Tampere European Council, Presidency Conclusions, 16/10/1999, No. 200/1/99, para. 5.

96. Draft Programme of Measures for Implementation of the Principle of Mutual Recognition of Decisions in Civil and Commercial Matters, Council (2001/C 12/01), 15.1.2001 Official Journal of the European Communities, at $\mathrm{C} 12 / 7$.

97. European Council, The Stockholm Programme - An Open and Secure Europe Serving and Protecting Citizens (2010/C 115/01), 4.5.2010 Official Journal of the European Union, p. C115/14.

98. Brussels I Recast Proposal, above n. 32.

99. See <www.uschamber.com/about-us/about-us-chamber> (last visited March 4, 2014).

100. Id. 
lawyers and legislators, the US Chamber of Commerce has advocated, among other things, for case-specific due process exceptions to recognition and enforcement of foreign country judgments. ${ }^{101}$ It is unsurprising that US business interests would favour such reforms. US business are, after all, especially likely to have substantial assets in the US that can be pursued by judgment creditors in enforcement actions.

In short, trust and distrust and governance values and rights values surely matter in the evolution of private international law in the EU and the US. But politics, it seems, may play a more fundamental role, whether its influence is exerted by a formal political mandate (as in the EU) or by the agenda-setting, lobbying and persuasive power of interest groups (as in the US).

\section{Conclusion}

Maybe Kagan is right - not just about strategic culture, but also about private international law. Europe and America are indeed different. EU law appears to exhibit more faith, and US law more scepticism, in a multilateral private international law approach to the enforcement of foreign country judgments. But it is far from clear that these transatlantic differences run as deep as those described by Kagan. To some extent, varying levels of trust and distrust and varying degrees of emphasis on governance values and rights values may be embedded in the EU and the US. But these factors are at least partially malleable at the hands of sufficiently focused political influence.

That said, the power of politics in private international law might be asymmetrical. As in other areas of politics, it is not difficult to create scepticism with a few good examples - even a few poor examples. For example, to support their argument for case-specific grounds of refusal such as those in the 2005 Act, business-oriented interest groups point to 'abusive foreign judgments' of Nicaraguan courts in Shell Oil Company v. Franco and Osorio v. Dole Food Company and of an Ecuadorian court in the Chevron/Ecuador case ${ }^{102}$ - but these examples would seem to be stronger evidence of the suitability of the traditional approach than for new case-specific exceptions, because in each case the court refused to recognise the foreign judgment on grounds other than the new case-specific exceptions. ${ }^{103}$ True, there is evidence

101. See US Chamber Institute for Legal Reform, 'Taming Tort Tourism: The Case for a Federal Solution to Foreign Judgment Recognition', September 2013, at 27; US Chamber Institute for Legal Reform, 'Confronting the New Breed of Transnational Litigation: Abusive Foreign Judgments', 102. Id October 2011

103. See Shell Oil Co. v. Franco, No. CV 03-8845 NM (PJWx), 2005 WL 6184247, at *1 (C.D. Cal. 2005) (denying enforcement of USD 489.4 million Nicaraguan judgment against Shell Oil); Osorio v. Dole Food Co., 655 F. Supp. 2d 1307 (S.D. Fla. 2009) (denying enforcement of USD 97 million Nicaraguan judgment against Dole Food Co.); Chevron Corporation v. Steven Donziger, Opinion, Case 1:11CV-00691-LAK-JCF, S.D.N.Y., March 4, 2014, p. 419 (holding that the judgments 14 not entitled to recognition). that foreign judgments against US defendants will increasingly be brought to US courts for enforcement ${ }^{104}$ - but this does not mean that those judgments are likely to be objectionable at a higher rate than before, or that when they are objectionable US judges will not decline to enforce them on traditional grounds of refusal. ${ }^{105}$

It would seem more difficult for politics to build faith in private international law. Yet this is what appears to be happening in the EU. In spite of enlargement's understandable challenges to mutual trust, and in spite of the limited progress of procedural and substantive legal harmonisation among EU member states, EU law continues its evolution toward greater facilitation of enforcement. In fact, this trend suggests a further comparative exercise, in which the EU's evolution might be likened to the evolution of sister-state enforcement of judgments in earlier US history, during which a political mandate - that of the US Constitution's full faith and credit clause - ultimately succeeded in creating an internal US 'market' in sister-state judgments notwithstanding periods of distrust among the states. The EU is not there yet. For example, whereas public policy is a ground for refusal under EU law, it is not a ground for refusal under the US law of full faith and credit. ${ }^{106}$ But it is interesting to ask whether the EU will ultimately reach the point of US-style internal full faith and credit. Such a comparison might yield valuable insights for lawyers, scholars and policymakers on both sides of the Atlantic.

104. See M.S. Quintanilla and C.A. Whytock, 'The New Multipolarity in Transnational Litigation: Foreign Courts, Foreign Judgments, and Foreign Law', 18 Southwestern Journal of International Law 31 (2011).

105. Moreover, in principle, if the foreign judicial system is systemically adequate, it should be able to address allegations of case-specific deficiencies through procedures analogous to those that exist in the US legal system for the same purposes such as rehearing and appellate procedures. Whytock and Robertson, above n. 58, at 1502 (arguing that '[i]f [...] the [foreign] judiciary is systemically adequate, then the casespecific inquiry should be unnecessary at the enforcement stage, because [the foreign judiciary] should be able to address case-specific inadequacies internally, through its own rehearing or appellate processes'). In that sense, case-specific exceptions may be redundant to the systemic due process exception.

106. See Baker v. General Motors Corp., 522 U.S. 222, 233 (1998) ('this Court's decisions support no roving "public policy exception" to the full faith and credit due judgments'). 